\title{
PEMANFAATAN LIMBAH TOMAT SEBAGAI AGEN DEKOMPOSER PEMBUATAN KOMPOS SAMPAH ORGANIK
}

Evi Dwi Ani, Isna Apriani, Yulisa Fitrianingsih

Program Studi Teknik Lingkungan, Jurusan Teknik Sipil, Fakultas Teknik Universitas Tanjungpura, Pontianak Email : evidwiani@yahoo.com

\begin{abstract}
ABSTRAK
Kurangnya pengetahuan terhadap tomat menyebabkan masyarakat memandangnya hanya sebagai buah atau sayur dan dijual begitu saja tanpa ada produk turunan. Sehingga limbah tomat yang busuk hanya dibuang begitu saja tanpa ada proses pengolahan. Oleh karena itu, diperlukan metode pengolahan sampah yang efisien dan ramah lingkungan seperti pengomposan. Penelitian ini dilakukan dengan memanfaatkan kulit pisang dan limbah tomat sebagai agen dekomposer untuk dijadikan kompos yang lebih bermanfaat. Tujuan dari penelitian ini untuk mengetahui kematangan kompos secara fisik (warna, bau, tekstur dan suhu) dan kimia $(\mathrm{pH}, \mathrm{N}, \mathrm{P}, \mathrm{K}$ dan $\mathrm{C} / \mathrm{N}$ rasio) berdasarkan SNI: 19-7030-2004. Penelitian ini diawali dengan pembuatan ekstrak limbah tomat. Pengomposaan dimulai dengan komposisi P1 (kulit pisang $1 \mathrm{~kg}$ ), P2 (kulit pisang $1 \mathrm{~kg}+$ limbah tomat 100g) dan P3 (kulit pisang + kotoran sapi), dimana penelitan dilakukan 2 kali pengulangan. Proses pengomposan dilakukan selama 8 minggu. Pengecekan pH, suhu, warna, bau dan tekstur dilakukan setiap hari. Selanjutnya dilakukan uji kualitas kompos dengan parameter Nitrogen $(\mathrm{N})$, fosfor $(\mathrm{P})$, kalium $(\mathrm{K})$ dan $\mathrm{C} / \mathrm{N}$ rasio dilakukan pada minggu ke- 6 dan minggu ke-8. Hasil pengomposan secara fisik menunjukkan warna kehitaman, tidak berbau, tekstur terurai seperti tanah dan suhu mendekati suhu tanah $\left(\mathrm{P} 1: 27,71^{\circ} \mathrm{C}, \mathrm{P} 2: 28,43^{\circ} \mathrm{C}\right.$ dan $\left.\mathrm{P} 3: 28,36^{\circ} \mathrm{C}\right)$. Sedangkan untuk parameter kimia secara berturut-turut yaitu $\mathrm{pH}(\mathrm{P} 1: 10,2, \mathrm{P} 2: 10,1$ dan $\mathrm{P} 3: 10,2), \mathrm{N}(\mathrm{P} 1: 2,28 \%, \mathrm{P} 2: 2,45 \%$ dan $\mathrm{P} 3: 2,22 \%), \mathrm{P}(\mathrm{P} 1: 0,38 \%, \mathrm{P} 2: 0,36 \%$ dan $\mathrm{P} 3: 0,39 \%)$, $\mathrm{K}(\mathrm{P} 1: 16,24 \%, \mathrm{P} 2: 15,20 \%$ dan $\mathrm{P} 3: 12,72 \%)$ dan $\mathrm{C} / \mathrm{N}$ rasio(P1:17,06\%, $\mathrm{P} 2: 16,73 \%$ dan $\mathrm{P} 3: 18,88)$. Berdasarkan SNI: 19-7030-2004, kadar minimum $\mathrm{N}$ yaitu $0,4 \%, \mathrm{P} 0,1 \%, \mathrm{~K} 0,2 \%$ dan $\mathrm{C} / \mathrm{N}$ rasio $10-$ 20 , sehingga kompos yang terbuat dari kulit pisang telah memenuhi standar kompos yang baik kecuali $\mathrm{pH}$.
\end{abstract}

Kata Kunci : limbah tomat, kompos, kulit pisang

\begin{abstract}
Lack of knowledge of the tomatoes causes people look at it just as a fruit or vegetable and sold just like that without any derivative product. Then the waite of tomatoes thrown without any processing. Therefore, we need a method of processing organic waste-efficient and environmentally friendly as composting. This research was conducted by using banana peels and the waste tomatoes as an agent of decomposer to produce the better compost. The porposes of this study was to determine the physical compost maturity (color, smell, texture and temperature) and chemical ( $p H, N, P, K$ and $C / N$ ratio) by SNI: 19-7030-2004. This research begins to extracting the tomatoes waste. The composting begins with the composition of $P 1$ (a banana peels $1 \mathrm{~kg}$ ), P2 (1 kg banana peels + waste tomatoes $100 \mathrm{~g})$ and P3 (1 kg banana peels + cow dung), where research is done in 2 replicates. The composting process is carried out for 8 weeks. Checking $\mathrm{pH}$, temperature, color, smell and texture will be done every day. Furthermore test the quality of compost with parameters Nitrogen $(N)$, phosphorus $(P)$, potassium $(K)$ and $C N$ ratio is performed at week 6 and week 8. Results composting physically showed blackish color, no smell, the texture of the soil and decompose as near room temperature (P1: $27,71^{\circ} \mathrm{C}, P 2: 28,43^{\circ} \mathrm{C}$ and $\left.P 3: 28,36^{\circ} \mathrm{C}\right)$. As for the chemical parameters respectively namely $\mathrm{pH}$ (P1: 10,2, P2: 10,1 and P3: 10,2), N (P1: 2,28\%, $P 2: 2,45 \%$ and $P 3: 2,22 \%), P(P 1: 0,38 \%, P 2: 0,36 \%$ and $P 3: 0,39 \%), K(P 1: 16,24 \%, P 2$ : 15,20\% and $P 3: 12,72 \%$ ) and $C / N$ ratio (P1: $17,06 \%, P 2: 16,73 \%$ and $P 3: 18,88)$. By SNI: $19-7030$ 2004 , minimum levels of $0.4 \% \mathrm{~N}, 0.1 \% \mathrm{P}, 0.2 \% \mathrm{~K}$ and $\mathrm{C} / \mathrm{N}$ ratio of $10-20$, then the compost made from banana peels has been standatds except $\mathrm{pH}$.
\end{abstract}

Keywords: banana peels, compost, tomato waste 


\section{PENDAHULUAN}

Bagi masyarakat tomat sudah tidak asing lagi dalam kehidupan sehari-hari, selain dibuat bumbu masakan juga enak bila dimakan mentah. Kurangnya pengetahuan terhadap tomat menyebabkan masyarakat memandangnya hanya sebagai buah atau sayur dan dijual begitu saja tanpa ada produk turunan. Sehingga pada tomat yang busuk berguguran di lahan atau sisa jualan di pasar hanya dibuang begitu saja tanpa ada proses pengolahan. Akibatnya banyak limbah tomat yang tidak terpakai dan hanya dibiarkan begitu saja. Sesuai dengan penelitian yang dilakukan oleh Anif dan Harismah (2004), menunjukkan bahwa limbah tomat mampu menggantikan peran EM-4 dalam proses pengomposan sampah organik, karena dalam limbah tomat mengandung jasad renik atau mikroba tertentu yang mampu mendekomposisi bahan organik dalam sampah. Sehingga perlakuan yang menggunakan limbah tomat mampu lebih cepat mendegradasi bahan kompos.

Selain menggunakan limbah tomat juga digunakan kotoran sapi sebagai dekomposer pembuatan kompos sampah organik. Kotoran sapi yang ditambahkan pada pembuatan kompos dapat membantu penguraian bahan padat organik oleh bakteri aerob (Erickson et al. 2008). Sampah organik yang digunakan pada penelitian ini yaitu kulit pisang. Kandungan karbohidrat pada kulit pisang yaitu $18,50 \%$ dan memiliki kadar air yang cukup tinggi yaitu $68,90 \%$ (Suprapti, 2005). Menurut Permana dan Hirasmawan (2008) menunjukan bahwa proses kematangan kompos kulit pisang dan sayuran memerlukan waktu 30 hari dalam menguraikan bahan organik. Namun, kulit pisang lebih lama terurai dibandingkan sampah sayuran dikarenakan kurangnya kandungan $\mathrm{N}$ yang dibutuhkan mikroorganisme untuk perkembangannya.

Berdasarkan pemaparan di atas, penulis akan meneliti tentang kualitas kematangan kompos secara fisik dan kimia dengan agen dekomposer limbah tomat dan kotoran sapi. Jika penelitian ini terbukti bahwa limbah tomat dapat menurunkan parameter kompos seperti $\mathrm{C} / \mathrm{N}$ rasio dan menambah kandungan hara $\mathrm{N}, \mathrm{P}$ dan $\mathrm{K}$, maka hal tersebut menjadi salah satu alternatif pengolahan sampah secara efisien.

\section{METODOLOGI PENELITIAN}

Adapun langkah-langkah yang harus dipersiapkan sebelum membuat kompos sebagai berikut:

a. ALAT

Alat penelitian yang digunakan meliputi keranjang bambu sebanyak 6 buah, plastik, pengaduk, pH meter, pisau/gunting, timbangan, karung goni, ember, sendok makan, tali rafia, termometer, alat untuk uji kualitas fisik kimia (labu ukur, erlenmeyer, spatula, pipit tetes spektrofotometer) dan peralatan penunjang seperti spidol water proof untuk menulis isi label, kertas, alat tulis dan kamera

\section{b. BAHAN}

Bahan penelitian yang digunakan adalah kulit pisang, ekstrak limbah tomat, kotoran sapi dan bahan untuk uji kualitas fisik kimia yaitu akuades, $\mathrm{K}_{2} \mathrm{Cr}_{2} \mathrm{O}_{7}$ (potassium dichromate), $\mathrm{H}_{2} \mathrm{SO}_{4}$ (asam sulfat), $\mathrm{NaOH}$ (natrium hidroksida), $\mathrm{HCl}$ (asam klorida).

\section{c. PROSEDUR PENELITIAN}

Menurut Anif dan Harismah (2004) tahapan proses pengomposan sebagai berikut: 


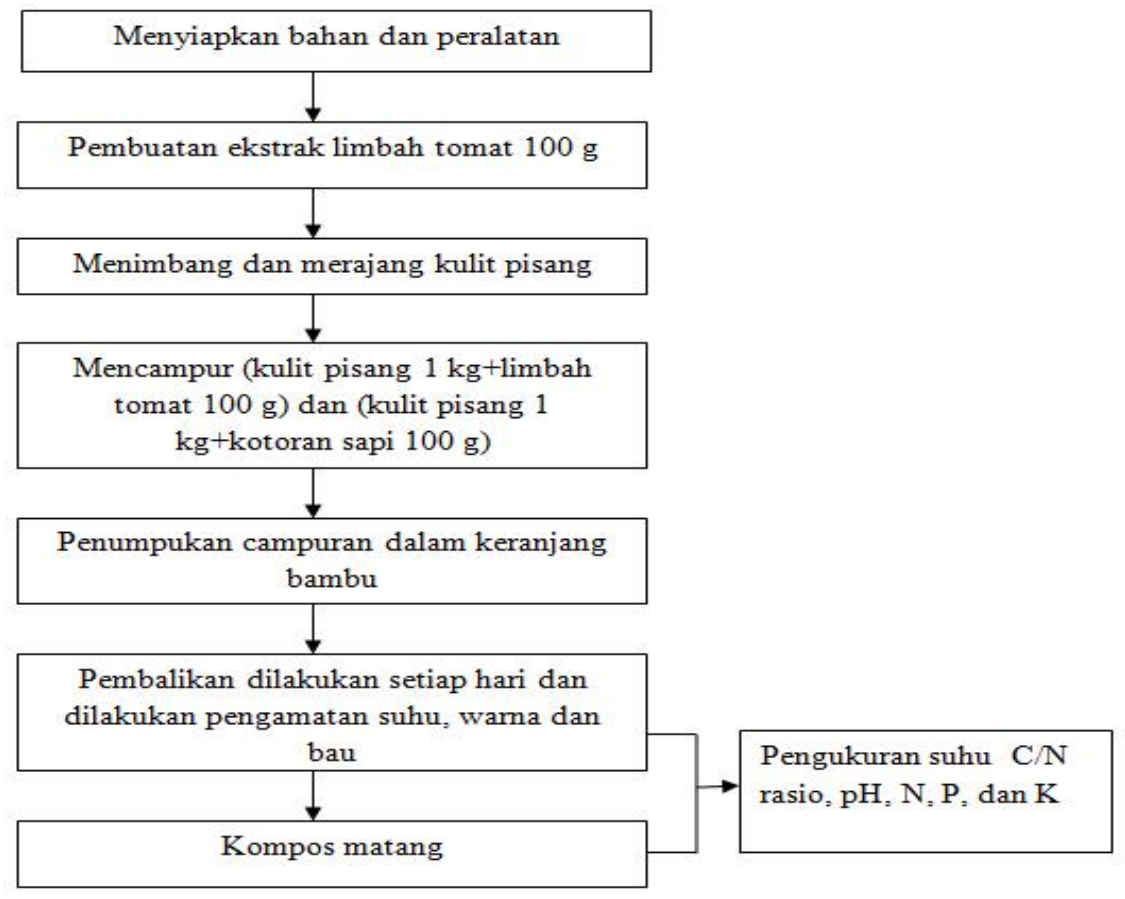

Gambar 1 Prosedur Penelitian

\section{d. TEKNIK ANALISA DATA}

Analisis data pada penelitian ini dilakukan secara deskriptif yang meliputi pengamatan kematangan kompos secara fisik yang dilihat dari warna coklat kehitaman, tidak bau dan tekstur menyerupai tanah, pengamatan tersebut dilakukn setiap hari. Sedangkan rincian analisis data yang dilakukan secara kimia dilakukan sebanyak 2 kali, pada 6 minggu dan 8 minggu. Masing-masing sampel dianalisis menggunakan metode spektofotometri untuk analisa nitrogen dan metode spektofotometer untuk analisa phospor, kalium dan karbon. Hasil yang didapatkan dibandingkan dengan standar SNI, apakah sudah sesuai dengan kriteria kematangan kompos

\section{HASIL DAN PEMBAHASAN}

a. KEMATANGAN KOMPOS SECARA FISIK

- Warna

Warna kompos selama penelitian dapat dilihat pada Tabel 1.

Tabel 1 Hasil Pengamatan Parameter Warna Kompos

\begin{tabular}{cccccccccc}
\hline Perlakuan & $\begin{array}{c}\text { Minggu } \\
\text { I }\end{array}$ & $\begin{array}{c}\text { Minggu } \\
\text { I }\end{array}$ & $\begin{array}{c}\text { Minggu } \\
\text { II }\end{array}$ & $\begin{array}{c}\text { Minggu } \\
\text { III }\end{array}$ & $\begin{array}{c}\text { Minggu } \\
\text { IV }\end{array}$ & $\begin{array}{c}\text { Minggu } \\
\text { V }\end{array}$ & $\begin{array}{c}\text { Minggu } \\
\text { VI }\end{array}$ & Minggu VII & Minggu VIII \\
\hline P1 & Coklat & Coklat & Coklat & $\begin{array}{c}\text { Coklat } \\
\text { Layu }\end{array}$ & $\begin{array}{c}\text { Coklat } \\
\text { Layu }\end{array}$ & $\begin{array}{c}\text { Coklat } \\
\text { Hitam }\end{array}$ & $\begin{array}{c}\text { Coklat } \\
\text { Hitam }\end{array}$ & $\begin{array}{c}\text { Coklat } \\
\text { Hitam }\end{array}$ & Kehitaman \\
P2 & Coklat & Coklat & $\begin{array}{c}\text { Coklat } \\
\text { Layu }\end{array}$ & $\begin{array}{c}\text { Coklat } \\
\text { Hitam }\end{array}$ & $\begin{array}{c}\text { Coklat } \\
\text { Hitam }\end{array}$ & $\begin{array}{c}\text { Coklat } \\
\text { Hitam }\end{array}$ & $\begin{array}{c}\text { Coklat } \\
\text { Hitam }\end{array}$ & Kehitaman & Kehitaman \\
P3 & Coklat & Coklat & Coklat & $\begin{array}{c}\text { Coklat } \\
\text { Layu }\end{array}$ & $\begin{array}{c}\text { Coklat } \\
\text { Hitam }\end{array}$ & $\begin{array}{c}\text { Coklat } \\
\text { Hitam }\end{array}$ & $\begin{array}{c}\text { Coklat } \\
\text { Hitam }\end{array}$ & Kehitaman & Kehitaman \\
& & & & & & & & & \\
\hline
\end{tabular}


Keterangan:

P1 : Kontrol (limbah kulit pisang $1 \mathrm{~kg}$ )

P2 : Limbah kulit pisang $1 \mathrm{~kg}+$ limbah tomat $100 \mathrm{~g}$

P3 : Limbah kulit pisang $1 \mathrm{~kg}+$ kotoran sapi $100 \mathrm{~g}$

Berdasarkan pengamatan parameter warna kompos menunjukkan bahwa perubahan warna kehitaman terjadi pada minggu ke-7 yaitu pada perlakuan P2 dan P3, sedangkan pada perlakuan P1 kompos warna hitam kecoklatan terjadi pada minggu ke8. Lambatnya proses pengomposan pada P1 disebabkan kurangnya aktifitas mikroorganisme di dalam bahan sehingga proses penguraian terjadi secara alami. Adanya perubahan warna pada kompos dilakukan oleh mikroorganisme dengan bantuan oksigen yang cukup sehingga dapat mengisolasi panas yang menyebabkan isi bahan kompos menjadi berkurang. Isi bahan dasar kompos berkurang atau menyusut 40-60\% tergantung bahan dasar yang digunakan (Musnawar, 2003).

- Bau

Bau kompos selama penelitian dapat dilihat pada Tabel 2.

Tabel 2 Hasil Pengamatan Parameter Bau Kompos

\begin{tabular}{cccccccccc}
\hline Perlakuan & $\begin{array}{c}\text { Minggu } \\
\text { 0 }\end{array}$ & $\begin{array}{c}\text { Minggu } \\
\text { I }\end{array}$ & $\begin{array}{c}\text { Minggu } \\
\text { II }\end{array}$ & $\begin{array}{c}\text { Minggu } \\
\text { III }\end{array}$ & $\begin{array}{c}\text { Minggu } \\
\text { IV }\end{array}$ & Minggu V & Minggu VI & $\begin{array}{c}\text { Minggu } \\
\text { VII }\end{array}$ & $\begin{array}{c}\text { Minggu } \\
\text { VIII }\end{array}$ \\
\hline P1 & Bau & Bau & Bau & Bau & Bau & Bau & Bau & Bau & Tidak \\
& Sampah & sampah & sampah & sampah & sampah & sampah & sampah & berkurang & bau \\
P2 & Bau & Bau & Bau & Bau & Bau & Bau & Bau & Tidak bau & Tidak \\
& Sampah & sampah & sampah & sampah & sampah & berkurang & berkurang & bau \\
P3 & Bau & Bau & Bau & Bau & Bau & Bau & Bau & Tidak bau & Tidak \\
& Sampah & sampah & sampah & sampah & sampah & berkurang & berkurang & & bau \\
\hline
\end{tabular}

Keterangan:

P1 : Kontrol (limbah kulit pisang $1 \mathrm{~kg}$ )

P2 : Limbah kulit pisang $1 \mathrm{~kg}+$ limbah tomat $100 \mathrm{~g}$

P3 : Limbah kulit pisang $1 \mathrm{~kg}+$ kotoran sapi $100 \mathrm{~g}$

Berdasarkan pengamatan parameter bau berkurang pada minggu ke-5 yaitu pada perlakuan P2 dan P3, diikuti dengan P1 bau berkurang pada minggu ke-7. Masingmasing perlakuan kompos tidak berbau lagi secara berturut-turut yaitu minggu ke-7 pada P2 dan P3 terakhir pada perlakuan P1 yaitu pada minggu ke-8. Hal ini disebabkan adanya dekomposer yang dapat memfermentasikan bahan organik yang terdapat di dalam bahan dengan melepaskan hasil fermentasi berupa gula, alkohol, vitamin, asam laktat, asam amino dan senyawa organik lainnya (Aminah dan Suparti, 2005). Fermentasi bahan organik melepaskan panas dan gas yang berbau busuk sehingga hasil fermentasi bahan organik menciptakan kondisi yang baik bagi pertumbuhan mikroorganisme. Semakin banyak jumlah mikroorganisme maka semakin baik karena berhubungan dengan cepatnya waktu penguraian. Menurut Permana dan Hirasmawan (2008), Kompos yang telah matang berbau seperti tanah karena materi yang dikandungnya sudah menyerupai materi tanah dan berwarna coklat kehitam-hitaman yang terbentuk akibat pengaruh bahan organik yang sudah stabil.

- Tekstur

Tekstur kompos selama penelitian dapat dilihat pada Tabel 3. 
Tabel 3 Hasil Pengamatan Parameter Tekstur Kompos

\begin{tabular}{|c|c|c|c|c|c|c|c|c|c|}
\hline Perlakuan & $\begin{array}{c}\text { Minggu } \\
0\end{array}$ & Minggu & $\begin{array}{c}\text { Minggu } \\
\text { II }\end{array}$ & $\begin{array}{c}\text { Minggu } \\
\text { III }\end{array}$ & $\begin{array}{l}\text { Minggu } \\
\text { IV }\end{array}$ & $\begin{array}{c}\text { Minggu } \\
\mathrm{V}\end{array}$ & $\begin{array}{c}\text { Minggu } \\
\text { VI }\end{array}$ & $\begin{array}{c}\text { Minggu } \\
\text { VII }\end{array}$ & $\begin{array}{l}\text { Minggu } \\
\text { VIII }\end{array}$ \\
\hline P1 & $\begin{array}{c}\text { Kulit } \\
\text { Pisang }\end{array}$ & $\begin{array}{c}\text { Kulit } \\
\text { Pisang }\end{array}$ & $\begin{array}{l}\text { Belum } \\
\text { Terurai }\end{array}$ & $\begin{array}{l}\text { Belum } \\
\text { Terurai }\end{array}$ & $\begin{array}{c}\text { Terurai } \\
\text { Kasar }\end{array}$ & $\begin{array}{c}\text { Terurai } \\
\text { Kasar }\end{array}$ & $\begin{array}{c}\text { Mulai } \\
\text { Terurai }\end{array}$ & Terurai & $\begin{array}{c}\text { Terurai } \\
\text { Seperti } \\
\text { Tanah }\end{array}$ \\
\hline P2 & $\begin{array}{l}\text { Kulit } \\
\text { Pisang }\end{array}$ & $\begin{array}{c}\text { Kulit } \\
\text { Pisang }\end{array}$ & $\begin{array}{l}\text { Belum } \\
\text { Terurai }\end{array}$ & $\begin{array}{c}\text { Terurai } \\
\text { Kasar }\end{array}$ & $\begin{array}{l}\text { Mulai } \\
\text { Terurai }\end{array}$ & Terurai & Terurai & $\begin{array}{c}\text { Terurai } \\
\text { Seperti } \\
\text { Tanah }\end{array}$ & $\begin{array}{c}\text { Terurai } \\
\text { Seperti } \\
\text { Tanah }\end{array}$ \\
\hline P3 & $\begin{array}{c}\text { Kulit } \\
\text { Pisang }\end{array}$ & $\begin{array}{c}\text { Kulit } \\
\text { Pisang }\end{array}$ & $\begin{array}{l}\text { Belum } \\
\text { Terurai }\end{array}$ & $\begin{array}{c}\text { Terurai } \\
\text { Kasar }\end{array}$ & $\begin{array}{c}\text { Terurai } \\
\text { Kasar }\end{array}$ & $\begin{array}{l}\text { Mulai } \\
\text { terurai }\end{array}$ & Terurai & $\begin{array}{c}\text { Terurai } \\
\text { Seperti } \\
\text { Tanah }\end{array}$ & $\begin{array}{c}\text { Terurai } \\
\text { Seperti } \\
\text { Tanah }\end{array}$ \\
\hline
\end{tabular}

Keterangan:

P1 : Kontrol (limbah kulit pisang $1 \mathrm{~kg}$ )

P2 : Limbah kulit pisang $1 \mathrm{~kg}+$ limbah tomat $100 \mathrm{~g}$

P3 : Limbah kulit pisang $1 \mathrm{~kg}+$ kotoran sapi $100 \mathrm{~g}$

Berdasarkan Tabel 3, menunjukkan perlakuan yang mengalami penguraian terlebih dahulu yaitu perlakuan $\mathrm{P} 2$ pada minggu ke-5, dilanjutkan dengan perlakuan $\mathrm{P} 3$ pada minggu ke- 6 dan yang terakhir perlakuan P1 pada minggu ke-9. Kompos terurai seperti butiran tanah terjadi pada minggu ke-8 pada semua perlakuan. Berarti perlakuan yang menggunakan dekomposer limbah tomat dan kotoran sapi lebih cepat terurai dibandingkan dengan kontrol dikarenakan di dalam limbah tomat dan kotoran sapi sudah terdapat mikroorganisme alami dari pembusukan tomat dan kotoran sapi tersebut. Sedangkan, pada kontrol cenderung lebih lama karena kurangnya mikroorganisme dalam merombak bahan kompos yang mengakibatkan kinerja mikroorganisme menurun. Seiring dengan terbentuknya warna dan bau di atas. Artinya, bahan kompos telah terdegradasi menjadi unsur hara (N, P dan K) maka pada saat itu pula warna kompos berubah menjadi coklat atau hitam kecoklatan, kompos tidak lagi berbau dan tekstur kompos sudah menunjukkan butiran seperti tanah (Anif dan Harismah, 2004)

- Suhu

Pengukuran suhu dilakukan setiap hari selama 8 minggu menggunakan alat thermometer. Adapun hasil pengukuran suhu dapat dilihat pada Gambar 2.

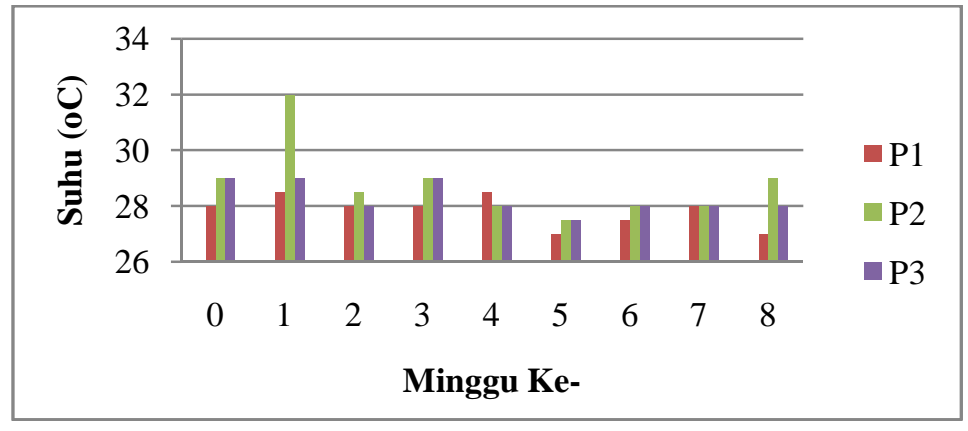

Gambar 2 Grafik Parameter Suhu Kompos 
Berdasarkan Gambar 2, pada minggu ke-0 masing-masing perlakuan $\mathrm{P} 1\left(28^{\circ} \mathrm{C}\right), \mathrm{P} 2$ $\left(29^{\circ} \mathrm{C}\right)$ dan $\mathrm{P} 3\left(29^{\circ} \mathrm{C}\right)$ mengalami fase masofilik (penghangatan) dimana mikroorganisme hadir dalam bahan kompos yang bertugas menguraikan ukuran bahan kompos. Suhu puncak pada penelitian ini terjadi pada minggu ke-1 pada perlakuan P2 sebesar $32^{\circ} \mathrm{C}$, dikarenakan oleh adanya aktivitas mikroorganisme yang mulai meningkat dalam merombak bahan kompos dan menghasilkan energi dalam bentuk panas sehingga suhu pada kompos meningkat.Suhu menurun kembali pada minggu ke-2 yaitu $\mathrm{P} 1\left(28^{\circ} \mathrm{C}\right), \mathrm{P} 2$ $\left(28,5^{\circ} \mathrm{C}\right)$ dan $\mathrm{P3}\left(28^{\circ} \mathrm{C}\right)$, berarti efektivitas kerja mikroorganisme cenderung menurun dan melemah dalam merombak bahan kompos. Suhu mengalami kanaikan dan penurunan pada minggu ke-5. Menurut Sidharta (2013) peningkatan dan penurunan suhu menandakan aktivitas mikroorganisme meningkat dan menurun dalam mengurai sampah organik. Perlakuan P2 dan P3 pada minggu ke-6-ke-8 sudah mendekati suhu tanah yaitu $29^{\circ} \mathrm{C}$ berarti mendekati kompos matang.

Ketinggian tumpukan bahan kompos yaitu $15 \mathrm{~cm}$. Kondisi ini tidak memungkinkan untuk mencapai fase termofilik dikarenakan tumpukan bahan yang terlalu rendah dan akan membuat bahan lebih cepat kehilangan panas, sehingga temperatur yang tinggi tidak dapat tercapai (Budi, et. al. 2015).Suhu yang tinggi pada proses pengomposan sangat penting untuk membunuh bakteri patogen dan bibit gulma. Tinggi rendahnya suhu kompos dipengaruhi oleh bahan pembuat kompos, jumlah mikroorganismedan kapasitas keranjang bambu yang tidak sesuai sehingga pori-pori udara terlalu banyak yang mengakibatkan panas yang dihasilkan keluar ke udara. Juga tidak terlepas dari faktor lingkungan yang mempengaruhinya, misalnya faktor cuaca yang tidak stabil, proses pembalikan sampah yang kurang merata dan kurang terkontrol. Proses pematangan kompos ditandai dengan penurunan suhu yang mendekati suhu tanah yaitu $29^{\circ} \mathrm{C}$ dan perubahan fisik kompos menjadi coklat kehitaman, terurai seperti butiran tanah dan tidak berbau dengan demikian ketiga sifat fisik kompos tersebut menjadi ciri khas kualitas kompos yang baik.

\section{b. KEMATANGAN KOMPOS SECARA KIMIA}

- Derajat Keasaman $(\mathrm{pH})$

Pengukuran $\mathrm{pH}$ juga dilakukan setiap hari selama 8 minggu menggunakan alat $\mathrm{pH}$ meter. Adapun hasil pengukuran pH dapat dilihat pada Gambar 3.

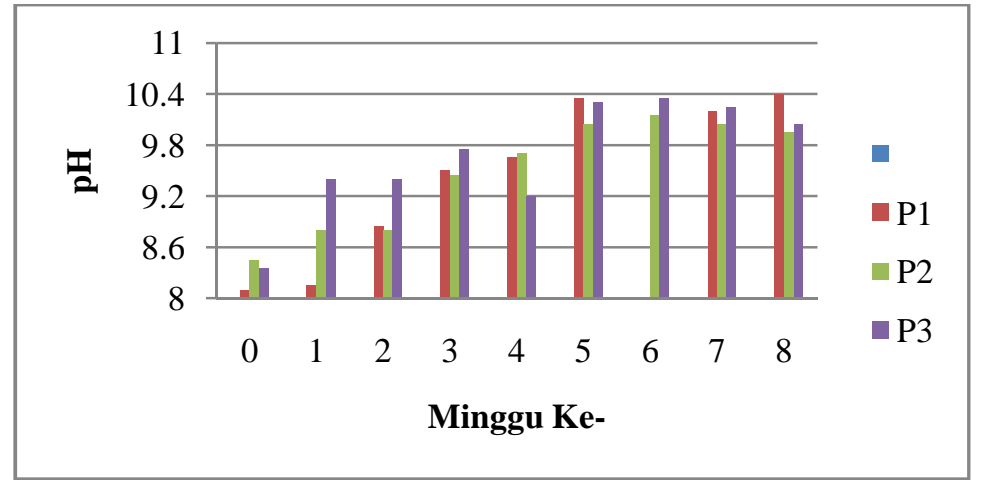

Gambar 3 Grafik Parameter pH Kompos

Berdasarkan Gambar 3, pada minggu ke-0 proses pengomposan rata-rata nilai $\mathrm{pH}$ cenderung basa. Perlakuan P1-P3 pH mengalami kenaikan hingga minggu ke-6 yaitu P1 $(10,45)$, p2 $(10,15)$ dan P3 $(10,35), \mathrm{pH}$ yang semakin meningkat ini dikarenakan tingginya 
aktivitas mikroorganisme pengurai pada bahan kompos. Ph mengalami penurunan kembali pada minggu ke-8pada perlakuan P2 $(9,95)$ dan P3 $(10,5)$ menandakan aktivitas mikroorganisme yang bekerja pada bahan kompos meningkat. Sedangkan perlakuan P1 $\mathrm{pH}$ naik dikarenakan kurangnya mikroorganisme yang merombak bahan kompos. Peningkatan dan penurunan $\mathrm{pH}$ menandakan adanya aktivitas penguraian bahan organik oleh mikroorganisme (Firdaus, 2011)

Menurut Manurung, (2011) peningkatan nilai pH kompos disebabkan adanya aktivitas mikroorganisme yang memberi masukan ion $\mathrm{OH}^{-}$dari hasil proses dekomposisi bahan kompos. Nilai pH pada pengamatan cenderung mengalami peningkatan disebabkan oleh sumbangan kation-kation basa hasil mineralisasi bahan kompos seperti $\mathrm{K}_{2}{ }^{+}, \mathrm{Ca}_{2}{ }^{+}$dan $\mathrm{Mg}_{2}{ }^{+}$, juga akibat dari penghancuran protein, penguapan amonia dan aktivitas mikroorganisme dalam pemecahan nitrogen organik dan reduksi sulfat (Permana, 2011).

- Nitrogen

Berdasarkan penelitian yang telah dilakukan, hasil pengujian kadar $\mathrm{N}$ pada penelitian ini dapat dilihat pada Tabel 4 berikut:

Tabel 4 Kadar Nitrogen Kompos

\begin{tabular}{|c|c|}
\hline Perlakuan & Kadar (\%) \\
\hline P1 & 2.28 \\
\hline P2 & 2.45 \\
\hline P3 & 2.22 \\
\hline
\end{tabular}

Berdasarkan Tabel 4, kandungan $\mathrm{N}$ tertinggi terjadi pada perlakuan $\mathrm{P} 2$ sebesar 2,45\%, diikuti dengan perlakuan $\mathrm{P} 1$ sebesar 2,28\% serta kandungan $\mathrm{N}$ terendah pada perlakuan $\mathrm{P} 3$ sebesar 2,22\%. Kandungan $\mathrm{N}$ pada ketiga perlakuan tersebut lebih tinggi dari kadar minimum berdasarkan SNI 19-7030-2004 sebesar 0,4\%. Kemampuan mikroorganisme yang terdapat pada perlakuan P2 lebih cepat mendegradasi bahan kompos dibandingkan dengan perlakuan P1 dan P3.Hal ini disebabkan adanya proses dekomposisi oleh mikroorganisme yang menghasilkan amonia dan $\mathrm{N}$ terperangkap di dalam tumpukan kompos karena pori-pori tumpukan kompos yang sangat kecil sehingga amonia dan nitrogen yang terlepas ke udara berada dalam jumlah yang sedikit (Cahaya dan Nugroho, 2004).

Kadar $\mathrm{N}$ dibutuhkan mikroorganisme untuk pemeliharaan dan pembentukan sel tubuh. Makin banyak kandungan nitrogen makin cepat bahan organik terurai, karena mikroorganisme pengurai memerlukan $\mathrm{N}$ untuk perkembangannya. Menurut Higa (1990), $\mathrm{N}$ diserap oleh akar tanaman dalam bentuk $\mathrm{NO}_{3}$ (nitrat) dan $\mathrm{NH}_{4}{ }^{+}$(amonium), sedangkan pupuk $\mathrm{N}$ diserap dalam bentuk nitrat $\left(\mathrm{NO}_{3}\right)$ dan ion nitrit $\left(\mathrm{NO}_{2}{ }^{-}\right)$. Nitrogen merupakan unsur hara utama bagi pertumbuhan tanaman yang sangat diperlukan untuk pembentukan atau pertumbuhan bagian-bagian vegetatif tanaman seperti daun dan batang.

\section{- Fosfor}

Berdasarkan penelitian yang telah dilakukan, hasil pengujian kadar P pada penelitian ini dapat dilihat pada Tabel 5. 
Tabel 5 Kadar Fosfor Kompos

\begin{tabular}{|c|c|}
\hline Perlakuan & Kadar (\%) \\
\hline P1 & 0.38 \\
\hline P2 & 0.36 \\
\hline P3 & 0.39 \\
\hline
\end{tabular}

Berdasarkan Tabel 5, kandungan $\mathrm{P}$ tertinggi terjadi pada perlakuan $\mathrm{P} 3$ sebesar $0,39 \%$, diikuti dengan perlakuan $P 1$ sebesar $0,38 \%$ serta kandungan $P$ terendah pada perlakuan $\mathrm{P} 2$ sebesar $0,36 \%$. Kandungan $\mathrm{P}$ pada ketiga perlakuan tersebut lebih tinggi dari kadar minimum berdasarkan SNI 19-7030-2004 sebesar 0,1\%. Mikroorganisme memiliki peran penting dalam penyerapan Fosfor. Kadar $P$ memiliki peran dalam kesuburan tanah dimana asupan nutrisi sangat membantu menaikkan kadar unsur hara tanah dalam mencapai intensitas kesuburan yang optimal.

Kandungan $\mathrm{P}$ dalam bahan kompos akan digunakan oleh sebagian besar mikroorganisme untuk membangun selnya. Mikroorganisme dalam bahan dapat mengubah nutrien menjadi $\mathrm{PO}_{4}{ }^{2-}$ yang mudahdiserap oleh tanaman. Kandungan $\mathrm{N}$ mempengaruhi $\mathrm{P}$ dalam pengomposan.Semakin besar $\mathrm{N}$ yang dikandung maka mikroorganisme yang merombak fosfor akan meningkat, sehingga kandungan fosfor dalam bahan komposan juga meningkat (Hidayati,et.al 2008). Kandungan Fosfor yang cukup tinggi dalam bahan berfungsi untuk pembentukan protein dan merangsang petumbuhan akar dan pembentukan anakan

- Kalium

Berdasarkan penelitian yang telah dilakukan, hasil pengujian kadar $\mathrm{K}$ pada penelitian ini dapat dilihat pada Tabel 6.

Tabel 6 Kadar Kalium Kompos

\begin{tabular}{|c|c|}
\hline Perlakuan & Kadar(\%) \\
\hline P1 & 16.24 \\
\hline P2 & 15.2 \\
\hline P3 & 12.72 \\
\hline
\end{tabular}

Berdasarkan Tabel 6, kandungan $\mathrm{K}$ tertinggi terjadi pada perlakuan $\mathrm{P} 1$ sebesar $16,24 \%$, diikuti dengan perlakuan P2 sebesar 15,20\% serta kandungan $\mathrm{K}$ terendah pada perlakuan $\mathrm{P} 3$ sebesar $12,72 \%$. Kandungan $\mathrm{K}$ pada ketiga perlakuan tersebut lebih tinggi dari kadar minimum berdasarkan SNI 19-7030-2004 sebesar 0,2\% .

Hal ini menunjukkan bahwa proses dekomposisi oleh mikroorganisme berjalan dengan baik. Kandungan K pada kontrol lebih besar dibandingkan dengan P2 dan P3 dikarenakan $\mathrm{K}$ dimakan oleh mikroorganisme yang terdapat pada limbah tomat dan kotoran sapi sehingga seiring dengan berjalannya waktu kandungan $\mathrm{K}$ menurun.Sedangkan pada kontrol tidak ada pemberian dekomposer sehingga mikroorganisme melarutkan kadar $\mathrm{K}$ secara alami tanpa bantuan mikroorganisme dari luar bahan.Kandungan kalium pada kulit pisang sudah cukup tinggi, tanpa dilakukan penambahan dekomposer juga sudah dapat mewakili standar minimum SNI.Hal tersebut didukung oleh pernyataan Agustina (2004), yang menyatakan bahwa kalium merupakan senyawa yang dihasilkan oleh metabolisme mikroorganisme, dimana mikroorganisme menggunakan ion-ion $\mathrm{K}^{+}$bebas yang ada pada bahan untuk keperluan metabolisme. Kalium memperkuat tubuh tanaman agar daun, bunga, dan buah tidak mudah gugur, 
selain itu kalium berperan sebagai sumber kekuatan bagi tanaman dalam menghadapi kekeringan dan penyakit.

- C/N Rasio

Berdasarkan penelitian yang telah dilakukan, hasil pengujian $\mathrm{C} / \mathrm{N}$ rasio pada penelitian ini dapat dilihat pada Tabel 7.

Tabel 7 Kandungan C/N rasio Kompos

\begin{tabular}{|c|c|}
\hline Perlakuan & C/N Rasio \\
\hline P1 & 17.06 \\
\hline P2 & 16.73 \\
\hline P3 & 18.88 \\
\hline
\end{tabular}

Berdasarkan Tabel 7, kandungan $\mathrm{C} / \mathrm{N}$ rasio pada perlakuan $\mathrm{P} 2$ sebesar 16,73 diikuti dengan perlakuan $\mathrm{P} 1$ sebesar 17,06 serta kandungan $\mathrm{C} / \mathrm{N}$ rasio pada perlakuan $\mathrm{P} 3$ sebesar 18,88 . Kandungan $\mathrm{C} / \mathrm{N}$ rasio pada ketiga perlakuan tersebut dibawah kadar minimum berdasarkan SNI 19-7030-2004 dengan rentang 10-20. Nilai yang mendekati $\mathrm{C} / \mathrm{N}$ rasio tanah yaitu P2 (mendekati 10 ). Apabila bahan organik mempunyai kandungan $\mathrm{C} / \mathrm{N}$ rasio mendekati atau sama dengan $\mathrm{C} / \mathrm{N}$ rasio tanah (10) maka bahan tersebut dapat diserap atau digunakan tanah dalam mencukupi unsur hara yang dibutuhkan oleh tanaman (Cooperband, 2000). C/N rasio pada P2 lebih rendah dibandingkan P1 dan P3 dikarenakan mikroorganisme yang bekerja dalam mendekomposisi bahan kompos pada P2 lebih besar dibandingkan dengan P1 dan P3.

Kandungan $\mathrm{C}$ akan dirombak oleh mikroorganisme dan digunakan sebagai sumber energi dalam proses metabolisme dan perbanyakan sel sehingga akan menghasilkan bahan buangan berupa asam organik dan alkohol. Sedangkan $\mathrm{N}$ digunakan untuk proses pembentuk protein dan pembentukan protoplasma. Jika bahan kompos memiliki kandungan $C$ terlalu tinggi maka proses penguraian akan berlangsung terlalu lama. Sebaliknya, jika $\mathrm{C}$ terlalu rendah maka sisa nitrogen akan berlebih sehingga akan terbentuk gas amoniak $\left(\mathrm{NH}_{3}\right)$ yang mengakibatkan $\mathrm{N}$ hilang ke udara. Banyaknya $\mathrm{N}$ yang hilang menyebabkan unsur $\mathrm{N}$ kompos rendah sehingga $\mathrm{C} / \mathrm{N}$ rasio kompos menjadi tinggi (Wahyunintyas dan Susanti, 2011). Menurut pendapat Hanafiah (2005), menyatakan bahwa kompos dengan kadar $\mathrm{C} / \mathrm{N}$ rasio yang tinggi tidak baik bagi tanaman dan pada saat pengaplikasian langsung ketanaman akan terjadi kompetisi antara tanaman dengan mikroba dalam penyerapan unsur hara, jika kadar $\mathrm{C} / \mathrm{N}$ rasio kompos rendah menyebabkan unsur hara yang terikat pada kompos telah dilepaskan melalui proses mineralisasi sehingga dapat digunakan oleh tanaman.

\section{KESIMPULAN}

Berdasarkan hasil penelitian yang telah dilakukan dapat disimpulkan, sebagai berikut:

1. Kualitas kematangan kompos secara fisik sesuai dengan persyaratan kompos matang berdasarkan SNI : 19-7030-2004 yaitu: berwarna kehitaman, tidak berbau, tekstur terurai menyerupai tanah terjadi pada perlakuan P2 (kulit pisang $1 \mathrm{~kg}+$ limbah tomat 100g) dan P3 (kulit pisang $1 \mathrm{~kg}+$ kotoran sapi 100g) diminggu ke-7 dan mendekati suhu tanah pada perlakuan $\mathrm{P} 2$ yaitu $29^{\circ} \mathrm{C}$.

2. Kadar N, P K sudah dibawah standar minimum SNI dan C/N rasio sudah berada pada rentangstandar kualitas kematangan kompos berdasarkan SNI : 19-70302004, sedangkan nilai pH berkisar 8,5-10,2, dikarenakan bahan tidak dapat 
mengisolasi panas menyebabkan peran mikroorganisme menurun dalam merombak bahan kompos sehingga suhunya menurun dan mengakibatkan kenaikan $\mathrm{pH}$

\section{UCAPAN TERIMA KASIH}

Dengan selesainya penelitian ini saya mengucapkan terima kasih yang sebesar-besarnya kepada Allah swt, kedua orang tua (bpk.Karsimin dan ibu Tumini), kedua dosen pembimbing yaitu Ibu Isna Apriani, S.T., M.Si dan ibu Yulisa Fitrianingsih, S.T., M.T. serta kepada teman-teman Teknik Lingkungan dan semua orang yang telah berperan dalam membantu penelitian yang tidak dapat disebutkan satu persatu. Harapan saya penelitian ini bermanfaat dan dapat dipergunakan sebagaimana mestinya.

\section{DAFTAR PUSTAKA}

Agustina. 2004. Dasar Nutrisi Tanaman. Jakart: Rineka Cipta

Aminah. A. dan Suparti. 2005. Model Pengembangan Pembuatan Pupuk Organik Dengan Inokulan (Studi Kasus Sampah di Tpa Mojosongo Surakarta). Jurnal Penelitian Sains dan Teknologi. Universitas Muhammadiyah Surakarta

Anif. S dan Harismah K.2004. Efektivitas Pemanfaatan Limbah Tomat Sebagai Pengganti EM4 Pada Proses Pengomposan Sampah Organik. Laporan Penelitian Dosen Muda, DP3M Dirjen Dikti. Surakarta: Fakultas Keguruan dan Ilmu Pendidikan UMS.

Budi. N.W, Wardah K.W, Edhi S. 2015. Pengaruh Rasio C/N Bahan Baku Pada Pembuatan Kompos Dari Kubis Dan Kulit Pisang. Jurnal Integrasi Proses. Vol. 1, No. 2

Cahaya. A.T. S. dan Nugroho, D. A. 2004. Pembuatan Kompos Dengan Menggunakan Limbah Padat Organik (Sampah Sayuran dan Ampas Tebu). Jurusan Teknik Kimia,Fakultas Teknik. Semarang: Universitas Diponegoro

Cooperband. L.R. 2000. Composting Art and Science of Organic Waste Conversion to a Valuable Soil Resource. Vol. 31, No. 6. Laboratory Medicine

Erickson. M., Critzer. F, and Doyle. M. 2008. Composting Criteria For Animal Manure. Produce Safety Project. Georgetown University.

Firdaus. F. 2011. Kualitas Pupuk Kompos Campuran Kotoran Ayam dan Batang Pisang Menggunakan Bioaktivator Mol Tapai. Bogor: IPB

Hanafiah. K.A. 2005. Dasar-Dasar Ilmu Tanah. Jakarta: Raja Grafindo Persada

Hidayati. Y. A., Ellin H., dan Eulis T.M. 2008. Upaya Pengolahan Feses Dombadan Limbah Usar (Vitiveria zizanioides) Melalui Barbagai Metode Pengomposan. Jurnal IImu Ternak. Vol 8, No1.

Higa, K. 1990. Production of Compost from Organic Water Food and Fertilizer Technology Center. Taiwan.

Manurung. H. 2011. Aplikasi Bioaktivator (Effective Microorganisme dan Orgadec) untuk Mempercepat Pembentukan Kompos Limbah Kulit Pisang Kepok. Jurusan Biologi. Universitas Mulawarman

Musnamar. E. L. 2003. Pupuk Organik Cair dan Padat. Jakarta: Penebar Swadaya

Permana. D. 2011. Kualitas Pupuk Organik Cair dari kotoran Sapi pedaging yang diferrmentasi menggunakan mikroorganisme Lokal. Bogor: IPB

Sidharta. R. 2013. Penggunaan Mikroorganisme Bonggol Pisang (Musa Paradisiaca) Sebagai Dekomposer Sampah Organik. Fakultas Teknobiologi. Yogyakarta: Universitas Atmajaya

Suprapti. M.L. 2005. Aneka Olahan Pisang. Yogyakarta: Kansius

Wahyuningtyas. R. S., dan P. D. Susanti. 2011. Karakteristik Kompos dari Enam Jenis Tumbuhan Bawah Lahan Gambut. Jakarta. 
